\title{
Pituitary Stem Cells: Quest for Hidden Functions
}

\author{
Hugo Vankelecom
}

\begin{abstract}
The pituitary is the core endocrine gland, ruling fundamental processes of body growth, metabolism, reproduction and stress. Over the past decade, it has progressively become clear that the pituitary, like many adult tissues, harbors a population of stem cells. While the molecular depiction of these cells is constantly expanding, their function remains essentially hidden. From recent studies, the picture is developing that the stem cells of the adult pituitary are highly quiescent and mainly come into play during pathological conditions.

Upon transgenic cell-ablation damage in the pituitary, the stem cell compartment is promptly turned on with expansion and expression of the missing hormone. This activation is accompanied by substantial regeneration of the lost hormonal cells, a restorative competence that was unexpected in the mature gland. This regenerative skill, however, rapidly disappears with aging, together with a decline in the number and fitness of the stem cells. One function of the adult pituitary stem cells may thus be hidden in the regenerative toolbox of the gland, at least during a specified and limited time window.

Recent work also showed activation of the pituitary stem cell compartment during tumor formation in the (mouse) gland. Moreover, pituitary tumors (from patients and mice) contain a candidate 'tumor stem cell' (TSC) population. The pathogenetic steps of initiation, expansion, invasion and recurrence of pituitary tumors remain far from understood. A link between the tumor-driving TSC and the pituitary stem cells may shed new light on this tumorigenic darkness.

To conclude, decoding the hidden functions of pituitary stem cells will not only lead to better fundamental insights into their role but may also expose (novel) targets for treating pituitary tumors and for regenerative intervention in pituitary deficiency, as caused by damage, tumors or aging. Yet, the journey in the 'hidden valley' of pituitary stem cell functions has only just begun, and a long distance still has to be walked.
\end{abstract}

\footnotetext{
H. Vankelecom $(\bowtie)$

Department of Development and Regeneration, Cluster of Stem Cell Biology and Embryology, Unit of Stem Cell Research, KU Leuven (University of Leuven), Campus Gasthuisberg O\&N4, Herestraat 49, 3000 Leuven, Belgium e-mail: Hugo.Vankelecom@kuleuven.be
} 


\section{Introduction}

The pituitary gland, in unison with the hypothalamus, constitutes the hub of our endocrine system, governing fundamental processes of growth, metabolism, sexual development, procreation and coping with immune and stress challenges (Melmed 2010; Vankelecom 2012; Willems and Vankelecom 2014). Due to this strategic position, malfunctioning of the pituitary leads to important morbidities that can be life-threatening (Schneider et al. 2007; Willems and Vankelecom 2014). In the past decade, mounting evidence has been presented that the endocrine gland contains a population of stem cells, purportedly sitting there to deal with renewal of cells that are worn out or have been damaged (Vankelecom 2012; Vankelecom and Chen 2014). However, like in comparable adult tissues that do not turn over very actively such as the brain and lung (Alvarez-Buylla and Lim 2004; Rando 2006; Slack 2008; Vankelecom 2012; Wabik and Jones 2015), the function of the stem cells residing in the pituitary remains enigmatic. Compared to the expanding molecular stripping of the pituitary stem cell phenotype, functional characterization of the cells clearly lags behind. In general, stem cells in 'lazy' low-turnover tissues are highly quiescent, and activation only clearly emerges in conditions of disease or damage (Barker et al. 2010; Huch et al. 2013a,b; Rando 2006; Slack 2008; Vankelecom 2012; Vankelecom and Chen 2014; Wabik and Jones 2015). Regarding the yet hidden functions of the pituitary stem cells, recent studies have shed some light on this obscure domain, particularly in the context of early postnatal maturation, damage repair and tumor growth. In this review, recent findings are summarized and emerging views presented. In addition, some brief perspectives are offered regarding therapeutic implementation of this new knowledge.

\section{Primer on Pituitary Biology and Pathology}

The pituitary gland consists of the anterior pituitary (AP), the posterior pituitary (PP) and the intermediate lobe (IL; Fig. 1), the latter being only rudimentary in humans (Melmed 2010; Vankelecom 2010, 2012). The AP represents the major endocrine segment of the gland, containing different cell types that each produce (a) specific hormone(s). Growth hormone $(\mathrm{GH})$ is produced by the somatotropes, prolactin (PRL) by lactotropes, adrenocorticotropic hormone (ACTH) by corticotropes, thyroid-stimulating hormone (TSH) by thyrotropes, and luteinizing hormone (LH) and/or follicle-stimulating hormone (FSH) by gonadotropes (Fig. 1). Hormone production by the AP is regulated by signals from the hypothalamus, such as growth hormone-releasing hormone (GHRH) and somatostatin, which stimulate and inhibit, respectively, pituitary GH synthesis and secretion. The pituitary hormones act on distal target organs where they mainly control the production of peripheral hormones (such as glucocorticoids from the adrenal cortex and estradiol or testosterone from the gonads), which in turn negatively feed back on the 


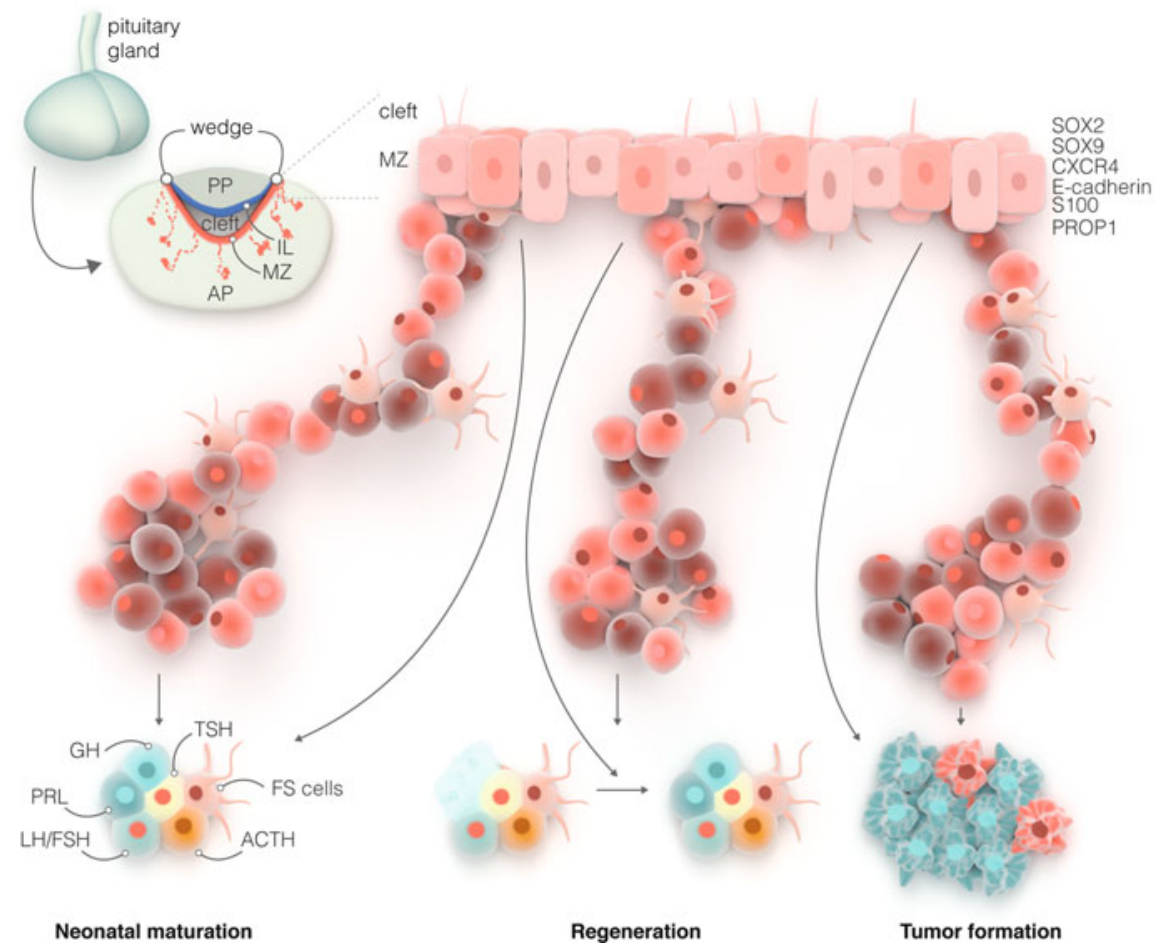

Fig. 1 Proposed model of pituitary stem cells and their functions. A cross-section of the (mouse) pituitary gland (upper left) shows the AP stem cell niche around the cleft (MZ; red) with the projected germinative wedge regions, and the putative secondary niches distributed all over the AP parenchyma (red clusters). The MZ stem cells and the in-gland stem cell clusters appear to be wired into a 3D network (see dotted lines in section and zoom-in drawing). The total stem cell pool is heterogeneous, encompassing stem (and further-advanced progenitor) cells in different phases of cell cycle, activation and maturation (indicated by different shapes and red tints), supposedly typified by different fingerprints of markers (of which the most dominant ones are indicated). To contribute to the pituitary endocrine cells, the stem/progenitor cells may move from the various niches into the glandular area (arrows), and EMT may be involved in this migration process. The pituitary stem cells are only modestly implicated in the low-rate turnover of the gland (see text) but appear to primarily pop up in the actively remodeling pituitary, as occurring during neonatal maturation (left), regeneration after cell/tissue destruction (middle), and development of tumors (with candidate TSC; red) (right). AP anterior pituitary, $F S$ folliculo-stellate, $I L$ intermediate lobe, $M Z$ marginal zone, $P P$ posterior pituitary

hypothalamus and pituitary. This multilayered interplay between hypothalamus, pituitary and target organs eventually generates tightly controlled, pulsatile secretion of hormones by the pituitary.

Because of its master position, disturbed function of the pituitary causes severe clinical complications (Schneider et al. 2007; Willems and Vankelecom 2014). For instance, GH deficiency causes growth disturbances and mental retardation in children and distorted fat metabolism, weakened muscles, osteoporosis and 
cardiovascular anomalies in adults, together strongly diminishing quality-of-life and life expectancy (Gasco et al. 2013). Pituitary deficiency (generally referred to as hypopituitarism) may be congenital or acquired during life, the latter accounting for the majority of cases (Mehta and Dattani 2008; Schneider et al., 2007; Willems and Vankelecom 2014; Zhu et al. 2005). Tumor growth in the pituitary (with a prevalence for clinically observed tumors of 1:1000) can compress the healthy endocrine tissue, thereby compromising pituitary function (Melmed 2011; Vankelecom 2012). Also the treatment procedures of surgical resection or irradiation inflict damage on the pituitary, resulting in hypofunction. In addition, traumatic brain injury, ranging from car accidents to sport-related impacts (e.g.,by boxing), represents an important cause of pituitary deficiency (Gasco et al. 2012; Tanriverdi et al. 2015). The current approach to treat hypopituitarism symptoms is by hormone replacement therapy (HRT) (Gasco et al. 2013; Schneider et al. 2007; Van Aken and Lamberts 2005; Willems and Vankelecom 2014). However, the exogenous hormones also cause side effects, further adding to the reduced quality-of-life. Moreover, a fundamental shortcoming of HRT lies in its failure to mimic the natural pulsatility of hormone release by the pituitary. Therefore, restoring deficient pituitary tissue and function would represent a more ideal tactic (Willems and Vankelecom 2014). Interestingly, it has recently been shown that the pituitary gland has the capacity to regenerate cells after destruction ( $\mathrm{Fu}$ and Vankelecom 2012; Fu et al. 2012). Moreover, the local stem cells appear to participate and function as activated restorers (see below). This new finding may open the door toward regenerative opportunities.

The process of tumorigenesis in the pituitary is largely uncomprehended, and treatment remains suboptimal in up to two-thirds of patients (Melmed, 2003, 2011). A better understanding of the underlying mechanisms is essential to improve clinical management. In particular, the question arises whether pituitary tumors contain a driver population of 'tumor stem cells' (TSC), as has been discovered in other types of tumors (Clevers 2011; Dalerba et al. 2007; Sergeant et al. 2009; Wouters et al. 2009). Generally speaking, TCS are considered to power the development, growth, local invasion, metastasis, therapy resistance and/or recurrence of tumors. TSC thus represent a very appealing target to understand, treat and eradicate the tumor.

\section{Pituitary Stem Cells: Expanding Molecular Portrayal}

Stem cells have now been identified in many adult organs. They are considered the master builders of the tissue, replacing cells that have grown old and finished their task (homeostatic turnover), producing surplus cells when needed, or regenerating cells that were destroyed by physical or pathological insults (Alvarez-Buylla and Lim 2004; Rando 2006; Slack 2008; Vankelecom 2012; Vankelecom and Chen 2014; Wabik and Jones 2015). The tissue stem cells not only give rise to new specialized cells of the organ but must also perpetuate by producing at least one 
'selfie.' Differentiation potential (ranging from uni- to multipotency) and selfrenewal capacity indeed represent the core hallmarks of adult tissue stem cells (Barker et al. 2010; De Los Angeles et al. 2015; Rando 2006; Wabik and Jones 2015). On the other hand, the degree of activity of adult stem cells is clearly dependent on the tissue. Some organs show rapid cell turnover within days and contain highly energetic stem cells that drive this renewal (as, for instance, intestine and skin). Other organs are more static in their cell composition and only need cell replacement at a very low pace (such as the brain, heart, liver, pancreas, lung; Alvarez-Buylla and Lim 2004; Barker et al. 2010; Huch et al. 2013a,b; Rando 2006; Slack 2008; Vankelecom 2012; Wabik and Jones 2015). The pituitary belongs to the latter group, undergoing turnover in terms of months rather than days (Levy 2002, 2008; Nolan et al. 1998; Rando 2006; Vankelecom 2012; Vankelecom and Chen 2014). Stem cells in organs with low turnover appear highly dormant (quiescent) and are only jolted awake by strong triggers like loss of cells by damage. Stem cells, together with their further progressed progenitor cells (that have set off for differentiation), are typically housed in a dedicated setting of the tissue, the niche, containing cellular and molecular 'housemates' that control the maintenance, selfrenewal and differentiation of the stem cell inhabitants (Alvarez-Buylla and Lim 2004; Rando 2006; Roskams 2006; Slack 2008; Vankelecom 2012; Vankelecom and Chen 2014; Yin et al. 2013).

The discovery of stem/progenitor cells in the pituitary was launched a decade ago by the identification of a side population (SP) in the adult gland of rodents and chicken (Chen et al. 2005). SP cells exhibit high efflux capacity, a property considered characteristic and important for stem cells to defend themselves against toxic substances. Meanwhile, the existence of stem cells in the pituitary has been clearly established (Chen et al. 2009; Fauquier et al. 2008; Garcia-Lavandeira et al. 2009). Their molecular portrayal is steadily expanding; a compact overview is provided here (for extensive reviews, see Vankelecom 2010, 2012; Vankelecom and Chen 2014).

Like stem cells of other tissues, pituitary stem cells in general express two classes of markers, i.e., broad stemness markers and pituitary embryogenesisassociated factors. Within the first group, the key stem-cell regulatory transcription factors SOX2 [SRY (sex determining region Y)-box 2] and SOX9 (Arnold et al. 2011; Jayakody et al. 2012; Pevny and Nicolis 2010) occupy a wellrecognized position. The SOX factors 'color' cells that reside in the marginal zone (MZ), which borders the cleft (Fig. 1), a lumen that is left from the earlyembryonic pituitary structure known as Rathke's pouch (RP; Vankelecom 2012). In addition, SOX2-immunoreactive $\left(\mathrm{SOX}^{+}\right)$cells are present as scattered clusters in the AP parenchymal area (Fig. 1; Chen et al. 2005, 2009; Fauquier et al. 2008; Fu et al. 2012; Garcia-Lavandeira et al. 2009; Gremeaux et al. 2012). The several locations of $\mathrm{SOX}^{+}$cells may point to the existence of multiple stem cell niches in the pituitary, encompassing a major (primary) niche around the cleft and many secondary parenchymal niches, together taking care of dynamic and/or subtle cell adaptations in the gland. Interestingly, the $\mathrm{SOX}^{+}$cell clusters and MZ cells appear to be connected (Fu et al. 2012; Gremeaux et al. 2012; Mollard et al. 2012; 
Vankelecom and Chen 2014), thereby forming a three-dimensional (3D) network throughout the gland (Fig. 1), as also occurs among the different hormonal cell types (Le Tissier et al. 2012; Mollard et al. 2012). Such an integrated circuit would allow communication between the stem cells throughout the gland and promote coordinated actions. Of note, the pituitary stem cells seem to be part of the formerly identified heterogeneous population of folliculo-stellate (FS) cells within the gland (Allaerts and Vankelecom 2005), since the stem cells also express the FS cell marker S100 (Fig. 1). Thus, the SOX2 ${ }^{+}$cell network may be part of the FS cell network, the first interconnected functional circuitry identified in the pituitary (Fauquier et al. 2001). In addition, the cell adhesion molecule E-cadherin (CDH1) is strongly expressed in the MZ, as well as in $\mathrm{S} 100^{+}$cell patches spread over the AP lobe (Fauquier et al. 2008), and may participate in stitching the stem cells together (Fig. 1). Additional general stemness markers found in pituitary stem cells, although sometimes less well-defined, include OCT4, NANOG, glial cell line-derived neurotrophic factor receptor alpha 2 (GFRA2), NESTIN and Krüppellike factor 4 (KLF4; reviewed in Vankelecom and Chen 2014). Of interest, SOX2, OCT4, NANOG and KLF4 constitute the transcription-factor core of embryonic stem (ES) and induced pluripotent stem (iPS) cells, the prototypical stem cells (De Los Angeles et al. 2015; Hyslop et al. 2005; Takahashi and Yamanaka 2006). Finally, the chemotactic receptor CXCR4 (C-X-C chemokine receptor type 4), which is more and more classified as a general stemness marker, is also upregulated in the pituitary stem cell compartment (Horiguchi et al. 2012; Vankelecom 2010, 2012; Vankelecom and Chen 2014).

Within the group of embryonic pituitary-related factors, expression of PROP1 (Prophet of Pit1) seems to be best defined. This transcription factor, which - among others - is essential for the regulation and migration of RP progenitor cells during pituitary embryogenesis (Himes and Raetzman 2009; Ward et al. 2005; Zhu et al. 2005, 2007), is expressed in the $\mathrm{SOX}^{+}$cells, although it is not clear yet whether postnatal expression in the MZ stops after the first postnatal weeks or is continuous throughout life (Garcia-Lavandeira et al. 2009; Yoshida et al. 2009, 2011). In general, there is no co-localization of PROP1 or SOX2 with hormones (Chen et al. 2009; Fauquier et al. 2008; Fu et al. 2012a,b; Garcia-Lavandeira et al. 2009; Gremeaux et al. 2012; Yoshida et al. 2009), supporting the general notion that stem cell conservators must be downregulated before differentiation starts. The NOTCH pathway is another essential regulator of pituitary embryogenesis (Kita et al. 2007; Monahan et al. 2009; Raetzman et al. 2004; Zhu et al. 2005, 2007), of which several components are upregulated in the adult (mouse) pituitary stem cell fraction (Chen et al. 2006, 2009; Vankelecom 2010) and are found expressed in some of the MZ and parenchymal $\mathrm{S}_{100}{ }^{+}$cells of the (rat) AP (Tando et al. 2013). Some other transcriptional regulators that play an important role in pituitary embryonic development (such as Hesxl, the earliest known gene expressed in the pituitary primordium, Lhx4, Pax6, Otx2, Ascll and the Six/Eyal Dach genes; Kelberman et al. 2009; Zhu et al. 2005, 2007) are also higher transcribed in the adult pituitary stem cell fraction (Chen et al. 2006, 2009; reviewed in Vankelecom 2010, 2012), as well as the cyclin-dependent kinase 
inhibitor $p 57$ that, during embryogenesis, emerges in the RP progenitor cells that stop cycling to embark on differentiation (Bilodeau et al., 2009; Vankelecom 2010; Vankelecom and Chen 2014). Finally, components of the fibroblast growth factor (FGF) and bone morphogenetic protein (BMP) pathways, having important roles in the specification and proliferation of RP progenitor cells (Ericson et al. 1998; Zhu et al. 2005, 2007), are also upregulated in the adult stem cells (Vankelecom 2010; Vankelecom and Chen 2014). Together, this expression portrait suggests that the stem cells of the adult pituitary (re-)use the embryonic developmental programs for their maintenance and progression toward differentiated cells (as also found in other tissues; Alvarez-Buylla and Lim 2004; Jensen et al. 2005; Roskams 2006; Slack 2008; Wagers and Conboy 2005).

Finally, a battery of new candidate markers has emerged from recent studies (extensively reviewed in Vankelecom 2010 and Vankelecom and Chen 2014), including the retinoic acid-producing retinal aldehyde dehydrogenase 1 (Raldhl; Fujiwara et al. 2007) and the retinoic acid receptor Rarb (Vankelecom 2010; Vankelecom and Chen 2014); the transcription factors PRRX1 and PRRX2 (expressed in proliferating RP progenitor cells until cell-cycle exit and start of differentiation; Susa et al. 2012); the cell-adhesion molecule cadherin-18 (expressed in the MZ in a different pattern than CDH1; Chauvet et al. 2009); the coxsackievirus and adenovirus receptor (CAR; Chen et al. 2013); the Krüppel-like factor 6 (KLF6; Ueharu et al. 2014); and the juxtacrine signaling molecule ephrinB2 (Yoshida et al. 2015). A number of the pituitary stem cell markers identified may be involved in constructing and maintaining the 3D network, in particular the cadherins, ephrins and CAR.

An intriguing question is how the multiple markers are distributed within the stem cell population. Regarding the embryonic markers, it can be assumed that different stages along the stem cell differentiation path are typified by different factors in a sequence similar to the embryogenic process. Accordingly, it is proposed that the pituitary stem cell compartment represents a heterogeneous pool of cells in different stages of life cycle and activation (Fig. 1), with the different markers, alone or in combination, designating the different phases, varying from quiescent stem cell states to committed precursor steps (reviewed in Vankelecom 2010, and Vankelecom and Chen 2014). Such heterogeneity within the stem cell population has also increasingly been demonstrated in other organs (Bond et al. 2015; Donati and Watt 2015). Single-cell transcriptomic analysis of brain stem cells identified the presence of four subgroups in different stages of activation (most prominently in response to injury), ranging from dormant to primed-quiescent, active and active-dividing stem cells (Llorens-Bobadilla et al. 2015). Of note, pituitary and brain stem cells show striking similarities, in particular regarding their localization around a lumen (cleft and ventricle, respectively) and their expression of common markers (such as SOX2, NESTIN and S100; Kriegstein and Alvarez-Buylla 2009). In addition, different stem cell subpopulations may be distributed over the different proposed niches in the pituitary. For instance, stem cells in the parenchymal $\mathrm{SOX}^{+}$cell clusters may be further advanced in their 'priming' (as compared to the MZ cells) to allow swifter 
contribution to the neigboring parenchymal endocrine tissue, or they may only form specific cell types more prevalent at the particular parenchymal spots.

Apart from their labeling value, the factors mentioned must, of course, also have a function in the pituitary stem cells. Not much is known yet about these duties, but ideas may be inferred from other stem cells or from pituitary embryogenesis. The transcription factors SOX2, OCT4, NANOG and KLF4 most likely play a role similar to the one in ES and iPS cells (De Los Angeles et al. 2015; Hyslop et al. 2005; Takahashi and Yamanaka 2006), i.e., to keep the pituitary stem cells in an undifferentiated, multipotent state. Genetic disruptions of SOX2 leads to certain forms of hormonal cell deficiency and pituitary hypoplasia (Jayakody et al. 2012; Kelberman et al. 2008), at least partly due to a reduced expansion and function of the RP progenitor cells, thereby giving some hint toward the importance of SOX2 in adult stem cell regulation. NOTCH signaling is likely also involved in the control of stem cell proliferation in the adult gland, since $\mathrm{NOTCH}$ downregulation in the embryonic pituitary coincides with cell cycle exit of the RP progenitor cells and genetic ablation of NOTCH signaling in the developing pituitary results in severe AP hypoplasia due to reduced proliferative capacity of RP progenitors (Kita et al. 2007; Monahan et al. 2009; Raetzman et al. 2004; Tando et al. 2013; Zhu et al. 2005, 2007). In addition, stem cells increase in number in AP cell cultures upon NOTCH activation (Chen et al. 2006; Tando et al. 2013). SOX2 and NOTCH (together with PROP1) may form an interacting signaling network within the stem cell compartment (reviewed in Willems and Vankelecom 2014).

In the adult pituitary, PROP1 may be required in the progressing stem/progenitor cells to enable migration from the $\mathrm{MZ}$ or the in-gland stem cell clusters toward the parenchyma for further differentiation. This proposed role is based on knowledge from embryogenesis, where genetic inactivation of PROP1 results in failure of RP progenitors to migrate from the proliferative progenitor region to the developing AP, resulting in extensive pituitary hypoplasia and absence of nearly all AP cell lineages (Himes and Raetzman 2009; Ward et al. 2005; Zhu et al. 2005, 2007). The prominent presence of the epithelial marker $\mathrm{CDH} 1$ and the tight-junction protein CAR suggests a role for these factors in stitching the marginal and parenchymal niches of stem cells together in a 3D network (Fig. 1). Escape from this 'imprisonment' would require conversion of the organized connected epithelial cell type to the untied and motile mesenchymal cell phenotype through the process of epithelial-mesenchymal transition (EMT; Kalluri and Weinberg 2009; Vankelecom and Chen 2014). PROP1 may be required for EMT since it downregulates CDH1 by activating the expression of the CDH1 repressor SNAI2/SLUG in the RP progenitor zone (Himes and Raetzman 2009). Stem cell migration in the adult gland may further be regulated by CXCR4, which is known for its chemotactic activity and regulation of EMT (Hu et al. 2014; Kalluri and Weinberg 2009). Also NESTIN ${ }^{+}$ pituitary cells have previously been shown to possess motile capacity (in vitro) as a possible result of EMT (Krylyshkina et al. 2005). Finally, ephrin signaling may play a role in the formation and organization of the proposed 3D stem cell network through actions of attraction and repulsion (Solanas and Batlle 2011). Taken 
together, a number of the factors identified seem to be involved in regulating the balance between movement and bonding of the pituitary stem cells.

In conclusion, the pituitary stem cell phenotyping list is progressively expanding. Although one can speculate on the role these markers play in adult pituitary stem cell regulation, a firm foundation remains to be provided.

\section{Pituitary Stem Cells: Uncovering the Hidden Functions}

As mentioned above, new tissue cells can be generated by the resident stem cells during homeostatic turnover, adaptive responses to body requirements and regenerative reactions to tissue damage (Alvarez-Buylla and Lim 2004; Rando 2006; Slack 2008; Vankelecom 2012; Vankelecom and Chen 2014; Wabik and Jones 2015). Whether stem cells in the pituitary also form or renew hormonal cells during postnatal life is a tempting question. Given the slow turnover rate of the adult gland (Levy 2002, 2008; Nolan et al. 1998; Rando 2006; Vankelecom 2012; Vankelecom and Chen 2014), the involvement of stem cells would be most evident in situations of more activated cell remodeling in the tissue. Recently, studies have started to explore the functional position of pituitary stem cells in more dynamic conditions, including neonatal maturation, adaptation to endocrine demands, regeneration after damage, and tumor formation.

\section{Neonatal Pituitary Maturation}

The (rodent) pituitary undergoes a substantial growth phase immediately after birth, with increasing numbers of hormonal cells developing during the first neonatal week(s) (Melmed 2010; Vankelecom 2010, 2012; Vankelecom and Chen 2014). During this period, the pituitary stem cell population resides in a state of activation as compared to later in life, showing higher cell numbers, higher proliferation rate and higher stem cell functionality (i.e., sphere-forming and multipotent differentiation capacity; Chen et al. 2005, 2009; Gremeaux et al. 2012). Moreover, stemness and embryonic markers are prominently expressed in neonatal stem cells (Chen et al. 2009; Gremeaux et al. 2012; Kikuchi et al. 2007). The topography of the $\mathrm{SOX}_{2}{ }^{+}$cells further underlines this higher activation status, with increased numbers of clusters in the neonatal AP lobe and higher abundance of $\mathrm{SOX}_{2}^{+}$cells at the junctions of the AP and IL (wedges), with signs of $\mathrm{SOX}^{+}$cells sprouting from these putative germinal regions (Gremeaux et al. 2012; Fig. 1). Neonatal SOX2 ${ }^{+}$ cell clusters in the vicinity of the MZ are clearly connected to the MZ (Gremeaux et al. 2012), supporting the idea that the cell clusters observed in the AP lobe originate from this zone (Fig. 1). Of note, SOX2 is mainly not observed together with hormones, which may be interpreted again as mutual exclusion, i.e., with 
differentiation only occurring when the guardians of multipotency like SOX2 are downregulated or extinguished.

Tracing of $\mathrm{SOX}^{+}$cells from embryonic to neonatal age (technically speaking, by tamoxifen induction in pregnant $\operatorname{Sox} 2^{\mathrm{CreERT}} / \mathrm{R} 26 \mathrm{YFP}^{\text {flox/flox }}$ mice) revealed traced 'yellow fluorescent protein'-positive $\left(\mathrm{YFP}^{+}\right)$cells in the neonatal pituitary that express early and late differentiation markers of hormonal cells, indicating that embryonic SOX2-expressing cells contribute to neonatal hormonal cells (Andoniadou et al. 2013; Rizzoti et al. 2013). It should be realized that this finding does not automatically mean that the neonatal stem cells per se drive the early expansion phase (by forming new hormonal cells) during those first weeks after birth. Short-term $\mathrm{SOX}^{+}$lineage tracing should, therefore, be done within the neonatal period itself. YFP was also found together with SOX2, indicating that the embryonic $\mathrm{SOX}_{2}{ }^{+}$progenitor cells persist after birth (e.g., by themselves or after self-renewal). Also in other tissues, $\mathrm{SOX}^{+}$postnatal (stem) cells originate from fetal $\mathrm{SOX}_{2}^{+}$(progenitor) cells (Arnold et al. 2011). This idea is also in line with the embryonic phenotype of the postnatal pituitary stem cells, as supported by the marker expression profile (see above).

Taken together, the activated nature of the stem cell compartment during the first weeks after birth suggests a dynamic participation in the neonatal maturation process of the gland, although most evidence so far is circumstantial.

\section{Basal and Adapting Adult Pituitary}

Basal Turnover The contribution of stem cells to the slow homeostatic turnover in the postnatal gland was only recently demonstrated (Andoniadou et al. 2013; Rizzoti et al. 2013). Tamoxifen-induced $\mathrm{SOX}^{+}$or $\mathrm{SOX}^{+}$lineage tracing starting from four to eight weeks of age revealed the existence of hormone ${ }^{+}$cells derived from the traced $\left(\mathrm{YFP}^{+}\right)$cells as analyzed 8 to 14 months later. However, their number was small, which in the first place reflects the low turnover rate of the adult gland under physiological conditions but at the same time suggests that the contribution of stem cells to new hormonal cells is only very limited under basal conditions. Endocrine cell turnover in the basal pituitary would thus mainly rely on proliferation of differentiated hormonal cells (Langlais et al. 2013; Vankelecom and Chen 2014). The vast majority of the $\mathrm{YFP}^{+}$cells were still $\mathrm{SOX}^{+} / \mathrm{SOX}^{+}$ after the long-term tracing, supporting a long-lived stem cell phenotype of high quiescence and/or a persistent (but slow) self-renewal activity. Taken together, the findings from lineage tracing do not support a major input of stem cells in adult pituitary homeostatic turnover, which is in line with findings in other 'lazy' tissues (Barker et al. 2010; Huch et al. 2013a,b; Rando 2006; Slack 2008; Vankelecom 2012; Wabik and Jones 2015).

Plastic Cell Adaptations In contrast to the quite immeasurable cell neogenesis under basal conditions, the pituitary's cell composition more actively changes in 
response to peripheral signals conveying endocrine needs. As a prominent example, the number (and activity) of lactotropes rises during pregnancy and lactation to meet the heightened demand for PRL (Haggi et al. 1986; Vankelecom 2012). This expansion is at least partly due to elevated estrogen levels in these conditions. The involvement of stem cells may be concluded from the recent observation that shortterm estradiol treatment (of male mice) causes a 10-fold increase in dividing SOX $2^{+}$ cells. The total number of SOX $2^{+}$cells, however, did not change, suggesting that the generated daughter cells immediately stopped expressing SOX2 to differentiate into the demanded lactotropes (Rizzoti et al. 2013). To underpin a direct contribution of stem cells to the expanding lactotrope population, lineage-tracing experiments are further needed. Whether the stem cells also play a role in the rise of somatotropes during puberty, or in the (continuous) adaptation of gonadotropes during sexual maturation and estrous cycling, is at present unknown.

Other forms of enhanced pituitary cell remodeling are seen when negative feedback dissipates because of ablation of target organs. Adrenalectomy causes a swift, transient rise in corticotropes, whereas gonadectomy triggers a fast and transitory increase in gonadotropes. Previous studies provided circumstantial evidence that 'hormonally null cells' (the at that time postulated pituitary stem cells) contribute to the new corticotropes and gonadotropes (Levy 2002, 2008; Nolan et al. 1998; Nolan and Levy 2006). Recent studies provided more direct evidence that pituitary stem cells are involved. The SOX $2^{+}$cells along the cleft expand after adrenalectomy (Langlais et al. 2013). In addition, SOX $9^{+}$lineage tracing showed that $\sim 20 \%$ of the newborn corticotropes are derived from the $\mathrm{SOX}^{+}$stem cells (Rizzoti et al. 2013). The other new $\mathrm{ACTH}^{+}$cells may be produced by corticotrope proliferation (see also Langlais et al. 2013). After gonadectomy, dividing SOX $2^{+}$ cells increase by four-fold but total $\mathrm{SOX}_{2}{ }^{+}$cell numbers do not change (Rizzoti et al. 2013), again suggesting that the generated progenitor cells immediately differentiate with prompt disappearance of SOX2.

Taken together, recent studies provide supportive evidence that adult pituitary stem cells have the capacity to differentiate into hormonal cells in vivo under challenging physio- and pathological conditions.

\section{Pituitary Regeneration and Impact of Aging}

A number of adult tissues are capable of restoring cells following destruction by physical or chemical impacts (Rando 2006; Vankelecom 2012; Vankelecom and Chen 2014; Willems and Vankelecom 2014; Wabik and Jones 2015). In several of these regenerative responses (like in muscle), stem cells are mobilized and directly involved to generate the new cells (Conboy and Rando 2005). Also in slowturnover organs like liver and pancreas, hidden ('facultative') stem cells are activated under certain damaging conditions to drive the regenerative reaction (Barker et al. 2010; Huch et al. 2013a,b; Rando 2006; Slack 2008; Vankelecom 2012; Wabik and Jones 2015; Xu et al. 2008). 
Regarding the pituitary, it has only recently been established that the adult, mature gland has the potential to regenerate cells after destruction. Through a transgenic mouse approach, damage was inflicted in the pituitary by killing the somatotrope $\left(\mathrm{GH}^{+}\right)$cells using diphtheria toxin (DT; Fu et al. 2012; Luque et al. 2011). The injury triggered an immediate response of the pituitary stem cells, which started to expand in number and to co-express $\mathrm{GH}$ (Fu et al. 2012). Five to six months after ablation, the somatotrope cell number was significantly restored (up to $60 \%$ ). The study for the first time showed that the pituitary, when suffering damage at adult age, has the potential to regenerate destroyed tissue (Fu et al. 2012). In addition, it advanced the stem cells as the likely drivers of regeneration (Fig. 1) and source of the newborn somatotropes. Meanwhile, this regenerative capability appeared more general and not limited to somatotropes. In an analogous model in which lactotropes were destroyed with DT (Fu and Vankelecom 2012), restoration was also observed (up to $~ 60 \%$ ) although clearly faster (already after four to six weeks), which may be due to the involvement and cooperation of more than one process. Stem cell participation with expansion and PRL co-expression was again observed, but in addition there was enhanced proliferation of the surviving (or newly formed) $\mathrm{PRL}^{+}$cells as well as increased numbers of double $\mathrm{PRL}^{+} / \mathrm{GH}^{+}$cells, suggestive of an activated transdifferentiaton process of somatotropes toward lactotropes (Fu and Vankelecom 2012). Finally, pituitary stem cells also expanded in number following gonadotrope ablation by DT, but detailed analysis of this mouse model was not possible because of cardiotoxicity (Vankelecom, unpublished observations).

A recent follow-up characterization study of the somatotrope ablation-andregeneration model revealed some interesting features of the pituitary's regenerative capacity (Willems et al. 2016). First, the regeneration level appeared to be capped (at $\sim 60 \%$, or in other words, restoration to $\sim 70 \%$ of the normal $\mathrm{GH}^{+}$cell number), even if the recovery period was largely extended from 0.5 to 1.5 year. Either the regenerative power of the pituitary does not go beyond certain levels or higher restoration is not needed to reach sufficient 'physiological' GH activity. Serum GH concentrations were restored to about one-third of normal values, at the same time indicating that regeneration does not only occur at the morphological level but also, although in a more limited fashion, at the functional (hormonesecretory) level. Furthermore, and rather surprisingly, the restorative capacity of the pituitary fades very fast at aging; middle-aged mice (eight months old) no longer showed recovery (as compared to eight-week-old mice), not even after long recuperation periods (Willems et al. 2016). Interestingly, this disappearance of regenerative competence coincides with a decline in pituitary stem cell number. Moreover, the stem cells of the older pituitary are less talented in generating spheres (as a functional characteristic of stem cells), which decrease in number and size, although differentiation to hormonal cell lineages still occurs in the spheres. SOX $2^{+}$signals in the spheres from the older pituitaries were most of the time found in the cytoplasm and not in the nucleus of the cells, where SOX2 should be present to maintain the stem cell phenotype (Willems et al. 2016). Taken together, these findings suggest a decrease in overall fitness of the pituitary stem 
cells at aging - not being maintained in a primitive state - which may lead to fast (-er) exhaustion of their potential during differentiation and regenerative attempts. In other tissues (e.g., muscle and heart), the stem cell population is also negatively affected by age, undergoing a decline in number and regenerative capacity (Blau et al. 2015; Hariharan and Sussman 2015).

Further intriguingly, restoration was not observed anymore when the injury impact was prolonged by extending the DT injection period (from 3 to 10 days), although the somatotrope ablation grade obtained was identical (Willems et al. 2016). The stem cell compartment still reacted to the prolonged injury by promptly expanding (although somewhat less than after the short-term injury impact), but no co-expression of GH was found despite the fact that the stem cells were still capable of differentiating into all hormonal cell types when assessed in vitro (using pituispheres; Willems et al. 2016). As found in other tissues (like the hippocampus and the hematopoietic system), the regenerative power may become exhausted when subsequent attempts are over and again suffocated during the longterm impact (Botnick et al. 1979; Sierra et al. 2015). Stem cells may have reached their expansive limit or crossed their threshold of restorative competence, or the reacting, regenerating stem cell pool may become depleted while possibly other, more quiet, stem cell populations remain unaffected (which would explain the preservation of sphere-forming and multipotent capacity). Alternatively, the observation of a remaining intrinsic functionality after prolonged DT treatment may suggest that a deficiency in stem cell regulatory networks, as emanating from the niche, pituitary parenchyma or systemic circulation, may lie at the basis of the regenerative failure.

Finally, our recent characterization study started to search for molecular mechanisms underlying regeneration and exposed some embryonic, stemness and repairing pathways that may be involved in the stem cell reaction to injury, in particular EMT, growth factor (FGF and epidermal growth factor, EGF) and Hippo pathways (Willems et al. 2016). Activation of FGF and EGF can lead to increased pituitary stem cell numbers, as has been demonstrated in AP cell aggregate cultures (Chen et al. 2006).

Taken together, recent studies support a function for pituitary stem cells in pituitary regeneration (Fig. 1). Activation of the stem cells and movement to the site of injury may be steered by embryonic, proliferative (growth factor), migratory (EMT) and restorative (Hippo) signaling pathways. This regenerative capacity appears not boundless but limited both in age-related terms and final efficacy.

\section{Pituitary Tumorigenesis}

As mentioned, the process of tumorigenesis in the pituitary remains far from understood (Melmed, 2003, 2011; Vankelecom and Gremeaux 2010; Vankelecom 2012). An appealing but largely untouched question is about the position of the pituitary stem cells during the tumorigenic event in the tissue. Furthermore, are 
TSC present in pituitary tumors, and if so, are they linked to the resident stem cells? Previous studies regarding this subject have been extensively reviewed before (Florio 2011; Lloyd et al. 2013; Vankelecom and Gremeaux 2010; Vankelecom 2012; Vankelecom and Chen 2014). Some candidate TSC were proposed, for instance, based on spheroid formation (Xu et al. 2009) and marker expression (Barbieri et al. 2008), but convincing evidence was not provided and some results remained questionable (discussed in Vankelecom and Gremeaux 2010; Vankelecom 2012; Vankelecom and Chen 2014).

A recent study of our group found that pituitary adenomas (as obtained from human patients) contain a SP with prominent expression of tumor stemness markers (like CXCR4) and stemness signaling pathways (like EMT) and that enriches for cells that form tumorspheres in a self-renewing sequence (Mertens et al. 2015). The pituitary tumor SP (as analyzed for the AtT20 cell line) showed tumor-growth advantage in vivo in immunodeficient mice. Thus, the pituitary tumor SP holds molecular and functional characteristics supporting a TSC phenotype. In addition, CXCR4 signaling may be involved in AtT20 tumorigenesis since inhibition of the pathway reduced tumor size in vivo as well as EMT activity (cell motility) in vitro (Mertens et al. 2015). Moreover, the AtT20 SP showed resistance to the chemotherapeutic drug temozolomide (Mertens and Vankelecom, unpublished observations), further supporting a TSC phenotype. Also interestingly, the SP of pituitary tumors displays some appealing molecular differences with the candidate TSC (SP) of malignant cancer types (melanoma and pancreatic cancer; Van den Broeck et al. 2013; Wouters et al. 2013) such as an upregulated senescence program, which might explain why pituitary tumors typically remain benign (Mertens and Vankelecom, unpublished observations).

The pituitary tumor SP also shows upregulated expression of SOX2 (Mertens et al. 2015), which may indicate either a link between the stem cells and the putative TSC or simply activation of SOX2 expression in the candidate TSC. Moreover, pituitaries from a mouse model in which pituitary $\left(\mathrm{PRL}^{+}\right)$tumors develop in situ (i.e., the dopamine receptor D2 knockout or Drd $2^{-/-}$mouse) contains more SP and $\mathrm{SOX}^{+}$cells than wildtype glands (Mertens et al. 2015). This observation is in accordance with the presence of a TSC (characterized by SP and SOX2 $2^{+}$phenotype) in the mouse pituitary tumors, adding up to the $\mathrm{SP}$ and $\mathrm{SOX}^{+}$cells of the surrounding normal tissue. In addition, or alternatively, the observation may point to an activated and expanded 'normal' stem cell compartment when tumorigenesis is occurring in the gland. Regarding the latter idea, it is not known yet what the consequence of pituitary stem cell activation may be. As already mentioned above, it is assumed that disappearance of SOX2 from the nucleus (by exclusion or active expulsion) is needed to allow differentiation (Chen et al. 2009; Fu et al. 2012; Vankelecom and Chen 2014; Willems and Vankelecom 2014), as has been demonstrated in ES cells (Baltus et al. 2009). The observation in Drd2 $2^{-/-}$pituitaries of a predominant increase in $\mathrm{SOX}_{2}^{+}$cells in which SOX2 is present in the cytoplasm (Mertens et al. 2015) might support a high(-er) differentiation rate toward the tumor $\mathrm{PRL}^{+}$cells. 
Alternatively, stem cell activation may represent a defence reaction or may paradoxically activate the TSC or feed the tumor by paracrine influences. An indirect role of $\mathrm{SOX}_{2}^{+}$stem cells as paracrine tumor-activating cells has also been suggested in a mouse model of adamantinomatous craniopharyngioma (Andoniadou et al. 2013; Gaston-Massuet et al. 2011; see also Andoniadou 2016), a pituitary tumor that originates from ectopic remnants of RP and in that way clearly differs from the typical AP tumors. On the other hand, resident stem cells may directly generate the TSC, as has been shown in some other tumor types (e.g., of intestine, skin and brain; Barker et al. 2009; Chen et al. 2012; Lapouge et al. 2011; Schepers et al. 2012). Stem cell lineage tracing in mouse models developing typical pituitary tumors is now needed to explore the link between tumorigenesis, TSC and stem cells in the pituitary.

Taken together, another hidden function of the pituitary stem cells may reside in the process of tumorigenesis (Fig. 1), either as the direct creators of the TSC or as the reacting compartment activated in response to the tumorigenic assault occurring in the tissue, resulting in a paracrine impact that likely is intended to defend the tissue but may eventually fuel the tumor.

\section{Conclusion and General Perspectives}

Recent studies have started to unveil the hidden functions of pituitary stem cells. Their job appears to primarily emerge in the active or challenged pituitary, i.e., during neonatal maturation, tumorigenesis and repair of damage (Fig. 1). The stem cells seem much less involved in the more subtle adaptations during basic turnover. Aging has an early and negative impact on the number and fitness of the pituitary stem cells, likely explaining the regenerative failure with advancing age. From the currently available data, embryonic programs appear to be recycled for postnatal stem cell regulation, activation and differentiation. Further efforts are needed to pinpoint the molecular mechanisms underlying the stem cell functions. An additional intriguing aspect to be deciphered is how the newborn endocrine cells topographically and functionally integrate into the (existing) hormonal cell networks.

More insight into the pituitary stem cell role and regulation may in the end advance the treatment of hypopituitarism patients, particularly within the context of regenerative medicine (extensively reviewed in Vankelecom and Chen 2014 and Willems and Vankelecom 2014). Pituitary stem cells may provide life-long cures for mutation-, surgery- and/or trauma-induced pituitary deficiencies. The endogenous stem cells may be stimulated to restore or repair the defective tissue, or the missing hormonal cells may be generated from stem cells ex vivo and implanted. The approaches are expected to be superior to HRT, which generates artificial hormone levels and cannot mimic hormone secretory cyclicity and pulsatility. However, many pressing issues remain, particularly regarding functional 
integration and safety, before moving to translational applications to cure conditions of hypopituitarism.

In sum, pituitary stem cells represent potential protagonists in the gland with still mysterious functions in pituitary biology and pathology, although recent studies have started to 'write' some possible scripts. Clearly, there remains a long way to go in the still under-explored domain of pituitary stem cell functions and associated clinical opportunities.

Open Access This chapter is distributed under the terms of the Creative Commons Attribution 4.0 International License (http://creativecommons.org/licenses/by/4.0/), which permits use, duplication, adaptation, distribution and reproduction in any medium or format, as long as you give appropriate credit to the original author(s) and the source, a link is provided to the Creative Commons license and any changes made are indicated.

The images or other third party material in this chapter are included in the work's Creative Commons license, unless indicated otherwise in the credit line; if such material is not included in the work's Creative Commons license and the respective action is not permitted by statutory regulation, users will need to obtain permission from the license holder to duplicate, adapt or reproduce the material.

\section{References}

Allaerts W, Vankelecom H (2005) History and perspectives of pituitary folliculo-stellate cell research. Eur J Endocrinol 153:1-12

Alvarez-Buylla A, Lim DA (2004) For the long run: maintaining germinal niches in the adult brain. Neuron 41:683-686

Andoniadou CL (2016) Pituitary stem cells during normal physiology and disease. In: Pfaff D, Christen Y (eds) Stem cells in neuroendocrinology. Springer, Heidelberg

Andoniadou CL, Matsushima D, Mousavy Gharavy SN, Signore M, Mackintosh AI, Schaeffer M, Gaston-Massuet C, Mollard P, Jacques TS, Le Tissier P, Dattani MT, Pevny LH, MartinezBarbera JP (2013) Sox2(+) stem/progenitor cells in the adult mouse pituitary support organ homeostasis and have tumor-inducing potential. Cell Stem Cell 13:433-445

Arnold K, Sarkar A, Yram MA, Polo JM, Bronson R, Sengupta S, Seandel M, Geijsen N, Hochedlinger K (2011) Sox2(+) adult stem and progenitor cells are important for tissue regeneration and survival of mice. Cell Stem Cell 9:317-329

Baltus GA, Kowalski MP, Zhai H, Tutter AV, Quinn D, Wall D, Kadam S (2009) Acetylation of sox2 induces its nuclear export in embryonic stem cells. Stem Cells 27:2175-2184

Barbieri F, Bajetto A, Stumm R, Pattarozzi A, Porcile C, Zona G, Dorcaratto A, Ravetti JL, Minuto F, Spaziante R, Schettini G, Ferone D, Florio T (2008) Overexpression of stromal cellderived factor 1 and its receptor CXCR4 induces autocrine/paracrine cell proliferation in human pituitary adenomas. Clin Cancer Res 14:5022-5032

Barker N, Ridgway R, van Es JH, van de Wetering M, Begthel H, van den Born M, Danenberg E, Clarke AR, Sansom OJ, Clevers H (2009) Crypt stem cells as the cells-of-origin of intestinal cancer. Nature 457:608-611

Barker N, Bartfeld S, Clevers H (2010) Tissue-resident adult stem cell populations of rapidly selfrenewing organs. Cell Stem Cell 7:656-670

Bilodeau S, Roussel-Gervais A, Drouin J (2009) Distinct developmental roles of cell cycle inhibitors p57Kip2 and p27Kip1 distinguish pituitary progenitor cell cycle exit from cell cycle reentry of differentiated cells. Mol Cell Biol 29:1895-1908 
Blau HM, Cosgrove BD, Ho AT (2015) The central role of muscle stem cells in regenerative failure with aging. Nat Med 21:854-862

Bond AM, Ming GL, Song H (2015) Adult mammalian neural stem cells and neurogenesis: five decades later. Cell Stem Cell 17:385-395

Botnick LE, Hannon EC, Hellman S (1979) Nature of the hemopoietic stem cell compartment and its proliferative potential. Blood Cells 5:195-210

Chauvet N, El-Yandouzi T, Mathieu MN, Schlernitzauer A, Galibert E, Lafont C, Le Tissier P, Robinson IC, Mollard P, Coutry N (2009) Characterization of adherens junction protein expression and localization in pituitary cell networks. J Endocrinol 202:375-387

Chen J, Hersmus N, Van Duppen V, Caesens P, Denef C, Vankelecom H (2005) The adult pituitary contains a cell population displaying stem/progenitor cell and early embryonic characteristics. Endocrinology 146:3985-3998

Chen J, Crabbe A, Van Duppen V, Vankelecom H (2006) The notch signaling system is present in the postnatal pituitary: marked expression and regulatory activity in the newly discovered side population. Mol Endocrinol 20:3293-3307

Chen J, Gremeaux L, Fu Q, Liekens D, Van Laere S, Vankelecom H (2009) Pituitary progenitor cells tracked down by side population dissection. Stem Cells 27:1182-1195

Chen J, Li Y, Yu TS, McKay RM, Burns DK, Kernie SG, Parada LF (2012) A restricted cell population propagates glioblastoma growth after chemotherapy. Nature 488:522-526

Chen M, Kato T, Higuchi M, Yoshida S, Yako H, Kanno N, Kato Y (2013) Coxsackievirus and adenovirus receptor-positive cells compose the putative stem/progenitor cell niches in the marginal cell layer and parenchyma of the rat anterior pituitary. Cell Tissue Res 354:823-836

Clevers H (2011) The cancer stem cell: premises, promises and challenges. Nat Med 17:313-319

Conboy IM, Rando TA (2005) Aging, stem cells and tissue regeneration - Lessons from muscle. Cell Cycle 4:407-410

Dalerba P, Cho RW, Clarke MF (2007) Cancer stem cells: models and concepts. Annu Rev Med $58: 267-284$

De Los AA, Ferrari F, Xi R, Fujiwara Y, Benvenisty N, Deng H, Hochedlinger K, Jaenisch R, Lee S, Leitch HG, Lensch MW, Lujan E, Pei D, Rossant J, Wernig M, Park PJ, Daley GQ (2015) Hallmarks of pluripotency. Nature 525:469-478

Donati G, Watt FM (2015) Stem cell heterogeneity and plasticity in epithelia. Cell Stem Cell 16:465-476

Ericson J, Norlin S, Jessell TM, Edlund T (1998) Integrated FGF and BMP signaling controls the progression of progenitor cell differentiation and the emergence of pattern in the embryonic anterior pituitary. Development 125:1005-1015

Fauquier T, Guerineau NC, McKinney RA, Bauer K, Mollard P (2001) Folliculostellate cell network: a route for long-distance communication in the anterior pituitary. Proc Natl Acad Sci USA 98:8891-8896

Fauquier T, Rizzoti K, Dattani M, Lovell-Badge R, Robinson IC (2008) SOX2-expressing progenitor cells generate all of the major cell types in the adult mouse pituitary gland. Proc Natl Acad Sci USA 105:2907-2912

Florio T (2011) Adult pituitary stem cells: from pituitary plasticity to adenoma development. Neuroendocrinology 94:265-277

Fu Q, Vankelecom H (2012) Regenerative capacity of the adult pituitary: multiple mechanisms of lactotrope restoration after transgenic ablation. Stem Cells Dev 21:3245-3257

Fu Q, Gremeaux L, Luque RM, Liekens D, Chen J, Buch T, Waisman A, Kineman R, Vankelecom $\mathrm{H}$ (2012) The adult pituitary shows stem/progenitor cell activation in response to injury and is capable of regeneration. Endocrinology 153:3224-3235

Fujiwara K, Kikuchi M, Takigami S, Kouki T, Yashiro T (2007) Expression of retinaldehyde dehydrogenase 1 in the anterior pituitary glands of adult rats. Cell Tissue Res 329:321-327

Garcia-Lavandeira M, Quereda V, Flores I, Saez C, Diaz-Rodriguez E, Japon MA, Ryan AK, Blasco MA, Dieguez C, Malumbres M, Alvarez CV (2009) A GRFa2/Prop1/stem (GPS) cell niche in the pituitary. PLoS One 4, e4815 
Gasco V, Prodam F, Pagano L, Grottoli S, Belcastro S, Marzullo P, Beccuti G, Ghigo E, Aimaretti G (2012) Hypopituitarism following brain injury: when does it occur and how best to test? Pituitary 15:20-24

Gasco V, Prodam F, Grottoli S, Marzullo P, Longobardi S, Ghigo E, Aimaretti G (2013) GH therapy in adult GH deficiency: a review of treatment schedules and the evidence for low starting doses. Eur J Endocrinol 168:R55-66

Gaston-Massuet C, Andoniadou CL, Signore M, Jayakody SA, Charolidi N, Kyeyune R, Vernay B, Jacques TS, Taketo MM, Le Tissier P, Dattani MT, Martinez-Barbera JP (2011) Increased Wingless (Wnt) signaling in pituitary progenitor/stem cells gives rise to pituitary tumors in mice and humans. Proc Natl Acad Sci USA 108:11482-11487

Gremeaux L, Fu Q, Chen J, Vankelecom H (2012) Activated phenotype of the pituitary stem/ progenitor cell compartment during the early-postnatal maturation phase of the gland. Stem Cells Dev 21:801-813

Haggi ES, Al T, Maldonado CA, Aoki A (1986) Regression of redundant lactotrophs in rat pituitary gland after cessation of lactation. J Endocrinol 111:367-373

Hariharan N, Sussman MA (2015) Cardiac aging - getting to the stem of the problem. J Mol Cell Cardiol 83:32-36

Himes AD, Raetzman LT (2009) Premature differentiation and aberrant movement of pituitary cells lacking both Hes1 and Prop1. Dev Biol 325:151-161

Horiguchi K, Ilmiawati C, Fujiwara K, Tsukada T, Kikuchi M, Yashiro T (2012) Expression of chemokine CXCL12 and its receptor CXCR4 in folliculostellate (FS) cells of the rat anterior pituitary gland: the CXCL12/CXCR4 axis induces interconnection of FS cells. Endocrinology 153:1717-1724

Hu TH, Yao Y, Yu S, Han LL, Wang WJ, Guo H, Tian T, Ruan ZP, Kang XM, Wang J, Wang SH, Nan KJ (2014) SDF-1/CXCR4 promotes epithelial-mesenchymal transition and progression of colorectal cancer by activation of the Wnt/ $\beta$-catenin signaling pathway. Cancer Lett 354:417-426

Huch M, Boj SF, Clevers H (2013a) Lgr5(+) liver stem cells, hepatic organoids and regenerative medicine. Regen Med 8:385-387

Huch M, Bonfanti P, Boj SF, Sato T, Loomans CJ, van de Wetering M, Sojoodi M, Li VS, Schuijers J, Gracanin A, Ringnalda F, Begthel H, Hamer K, Mulder J, van Es JH, de Koning E, Vries RG, Heimberg H, Clevers H (2013b) Unlimited in vitro expansion of adult bi-potent pancreas progenitors through the Lgr5/R-spondin axis. EMBO J 32:2708-2721

Hyslop LA, Armstrong L, Stojkovic M, Lako M (2005) Human embryonic stem cells: biology and clinical implications. Expert Rev Mol Med 7:1-21

Jayakody SA, Andoniadou CL, Gaston-Massuet C, Signore M, Cariboni A, Bouloux PM, Le Tissier P, Pevny LH, Dattani MT, Martinez-Barbera JP (2012) SOX2 regulates the hypothalamic-pituitary axis at multiple levels. J Clin Invest 122:3635-3646

Jensen JN, Cameron E, Garay MVR, Starkey TW, Gianani R, Jensen J (2005) Recapitulation of elements of embryonic development in adult mouse pancreatic regeneration. Gastroenterology 128:728-741

Kalluri R, Weinberg RA (2009) The basics of epithelial-mesenchymal transition. J Clin Invest 119:1420-1428

Kelberman D, de Castro SC, Huang S, Crolla JA, Palmer R, Gregory JW, Taylor D, Cavallo L, Faienza MF, Fischetto R, Achermann JC, Martinez-Barbera JP, Rizzoti K, Lovell-Badge R, Robinson IC, Gerrelli D, Dattani MT (2008) SOX2 plays a critical role in the pituitary, forebrain, and eye during human embryonic development. J Clin Endocrinol Metab 93:1865-1873

Kelberman D, Rizzoti K, Lovell-Badge R, Robinson IC, Dattani MT (2009) Genetic regulation of pituitary gland development in human and mouse. Endocr Rev 30:790-829

Kikuchi M, Yatabe M, Kouki T, Fujiwara K, Takigami S, Sakamoto A, Yashiro T (2007) Changes in E- and N-cadherin expression in developing rat adenohypophysis. Anat Rec (Hoboken) 290:486-490 
Kita A, Imayoshi I, Hojo M, Kitagawa M, Kokubu H, Ohsawa R, Ohtsuka T, Kageyama R, Hashimoto N (2007) Hes1 and Hes5 control the progenitor pool, intermediate lobe specification, and posterior lobe formation in the pituitary development. Mol Endocrinol 21:1458-1466

Kriegstein A, Alvarez-Buylla A (2009) The glial nature of embryonic and adult neural stem cells. Annu Rev Neurosci 32:149-184

Krylyshkina O, Chen J, Mebis L, Denef C, Vankelecom H (2005) Nestin-immunoreactive cells in rat pituitary are neither hormonal nor typical folliculo-stellate cells. Endocrinology 146:2376-2387

Langlais D, Couture C, Kmita M, Drouin J (2013) Adult pituitary cell maintenance: lineage specific contribution of self-duplication. Mol Endocrinol 27:1103-1112

Lapouge G, Youssef KK, Vokaer B, Achouri Y, Michaux C, Sotiropoulou PA, Blanpain C (2011) Identifying the cellular origin of squamous skin tumors. Proc Natl Acad Sci USA 108:7431-7436

Le Tissier PR, Hodson DJ, Lafont C, Fontanaud P, Schaeffer M, Mollard P (2012) Anterior pituitary cell networks. Front Neuroendocrinol 33:252-266

Levy A (2002) Physiological implications of pituitary trophic activity. J Endocrinol 174:147-155

Levy A (2008) Stem cells, hormones and pituitary adenomas. J Neuroendocrinol 20:139-140

Llorens-Bobadilla E, Zhao S, Baser A, Saiz-Castro G, Zwadlo K, Martin-Villalba A (2015) Singlecell transcriptomics reveals a population of dormant neural stem cells that become activated upon brain injury. Cell Stem Cell 17:329-340

Lloyd RV, Hardin H, Montemayor-Garcia C, Rotondo F, Syro LV, Horvath E, Kovacs K (2013) Stem cells and cancer stem-like cells in endocrine tissues. Endocr Pathol 24:1-10

Luque RM, Lin Q, Cordoba-Chacon J, Subbaiah PV, Buch T, Waisman A, Vankelecom H, Kineman RD (2011) Metabolic impact of adult-onset, isolated, growth hormone deficiency (AOiGHD) due to destruction of pituitary somatotropes. PLoS One 6, e15767

Mehta A, Dattani MT (2008) Developmental disorders of the hypothalamus and pituitary gland associated with congenital hypopituitarism. Best Pract Res Clin Endocrinol Metab 22:191-206

Melmed S (2003) Mechanisms for pituitary tumorigenesis: the plastic pituitary. J Clin Invest 112:1603-1618

Melmed S (2010) The pituitary, 3rd edn. Academic, New York

Melmed S (2011) Pathogenesis of pituitary tumors. Nat Rev Endocrinol 7:257-266

Mertens F, Gremeaux L, Chen J, Fu Q, Willems C, Roose H, Govaere O, Roskams T, Cristina C, Becú-Villalobos D, Jorissen M, Poorten VV, Bex M, van Loon J, Vankelecom H (2015) Pituitary tumors contain a side population with tumor stem cell-associated characteristics. Endocr Relat Cancer 22:481-504

Mollard P, Hodson DJ, Lafont C, Rizzoti K, Drouin J (2012) A tridimensional view of pituitary development and function. Trends Endocrinol Metab 23:261-269

Monahan P, Rybak S, Raetzman LT (2009) The notch target gene HES1 regulates cell cycle inhibitor expression in the developing pituitary. Endocrinology 150:4386-4394

Nolan LA, Levy A (2006) A population of non-luteinising hormone/non-adrenocorticotrophic hormone-positive cells in the male rat anterior pituitary responds mitotically to both gonadectomy and adrenalectomy. J Neuroendocrinol 18:655-661

Nolan LA, Kavanagh E, Lightman SL, Levy A (1998) Anterior pituitary cell population control: basal cell turnover and the effects of adrenalectomy and dexamethasone treatment. J Neuroendocrinol 10:207-215

Pevny LH, Nicolis SK (2010) Sox2 roles in neural stem cells. Int J Biochem Cell Biol 42:421-424

Raetzman LT, Ross SA, Cook S, Dunwoodie SL, Camper SA, Thomas PQ (2004) Developmental regulation of Notch signaling genes in the embryonic pituitary: Prop1 deficiency affects Notch2 expression. Dev Biol 265:329-340

Rando TA (2006) Stem cells, ageing and the quest for immortality. Nature 441:1080-1086

Rizzoti K, Akiyama H, Lovell-Badge R (2013) Mobilized adult pituitary stem cells contribute to endocrine regeneration in response to physiological demand. Cell Stem Cell 13:419-432

Roskams T (2006) Different types of liver progenitor cells and their niches. J Hepatol 45:1-4 
Schepers AG, Snippert HJ, Stange DE, van den Born M, van Es JH, van de Wetering M, Clevers H (2012) Lineage tracing reveals Lgr5+ stem cell activity in mouse intestinal adenomas. Science 337:730-735

Schneider HJ, Aimaretti G, Kreitschmann-Andermahr I, Stalla GK, Ghigo E (2007) Hypopituitarism. Lancet 369:1461-1470

Sergeant G, Vankelecom H, Gremeaux L, Topal B (2009) Role of cancer stem cells in pancreatic ductal adenocarcinoma. Nat Rev Clin Oncol 6:580-586

Sierra A, Martin-Suarez S, Valcarcel-Martin R, Pascual-Brazo J, Aelvoet SA, Abiega O, Deudero JJ, Brewster AL, Bernales I, Anderson AE, Baekelandt V, Maletic-Savatic M, Encinas JM (2015) Neuronal hyperactivity accelerates depletion of neural stem cells and impairs hippocampal neurogenesis. Cell Stem Cell 216:488-503

Slack JM (2008) Origin of stem cells in organogenesis. Science 322:1498-1501

Solanas G, Batlle E (2011) Control of cell adhesion and compartmentalization in the intestinal epithelium. Exp Cell Res 317:2695-2701

Susa T, Kato T, Yoshida S, Yako H, Higuchi M, Kato Y (2012) Paired-related homeodomain proteins Prx 1 and Prx 2 are expressed in embryonic pituitary stem/progenitor cells and may be involved in the early stage of pituitary differentiation. J Neuroendocrinol 24:1201-1212

Takahashi K, Yamanaka S (2006) Induction of pluripotent stem cells from mouse embryonic and adult fibroblast cultures by defined factors. Cell 126:663-676

Tando Y, Fujiwara K, Yashiro T, Kikuchi M (2013) Localization of Notch signaling molecules and their effect on cellular proliferation in adult rat pituitary. Cell Tissue Res 351:511-519

Tanriverdi F, Schneider HJ, Aimaretti G, Masel BE, Casanueva FF, Kelestimur F (2015) Pituitary dysfunction after traumatic brain injury: a clinical and pathophysiological approach. Endocr Rev 36:305-342

Ueharu H, Higuchi M, Nishimura N, Yoshida S, Shibuya S, Sensui K, Kato T, Kato Y (2014) Expression of Krüppel-like factor 6, KLF6, in rat pituitary stem/progenitor cells and its regulation of the PRRX2 gene. J Reprod Dev 60:304-311

Van Aken MO, Lamberts SW (2005) Diagnosis and treatment of hypopituitarism: an update. Pituitary 8:183-191

Van den Broeck A, Vankelecom H, Van Delm W, Gremeaux L, Wouters J, Allemeersch J, Govaere O, Roskams T, Topal B (2013) Human pancreatic cancer contains a side population expressing cancer stem cell-associated and prognostic genes. PLoS One 8, e73968

Vankelecom H (2010) Pituitary stem/progenitor cells: embryonic players in the adult gland? Eur J Neurosci 32:2063-2081

Vankelecom H (2012) Pituitary stem cells drop their mask. Curr Stem Cell Res Ther 7:36-71

Vankelecom H, Chen J (2014) Pituitary stem cells: where do we stand? Mol Cell Endocrinol 385:2-17

Vankelecom H, Gremeaux L (2010) Stem cells in the pituitary gland: a burgeoning field. Gen Comp Endocrinol 166:478-488

Wabik A, Jones PH (2015) Switching roles: the functional plasticity of adult tissue stem cells. EMBO J 34:1164-1179

Wagers AJ, Conboy IM (2005) Cellular and molecular signatures of muscle regeneration: current concepts and controversies in adult myogenesis. Cell 122:659-667

Ward RD, Raetzman LT, Suh H, Stone BM, Nasonkin IO, Camper SA (2005) Role of PROP1 in pituitary gland growth. Mol Endocrinol 19:698-710

Willems C, Vankelecom H (2014) Pituitary cell differentiation from stem cells and other cells: towards restorative therapy for hypopituitarism? Regen Med 9:513-534

Willems C, Fu Q, Roose H, Mertens F, Cox B, Chen J, Vankelecom H (2016) Regeneration in the pituitary after cell-ablation injury: time-related aspects and molecular analysis. Endocrinology 157:705-21

Wouters J, Vankelecom H, van den Oord J (2009) Cancer stem cells in cutaneous melanoma. Expert Rev Dermatol 4:225-235 
Wouters J, Stas M, Gremeaux L, Govaere O, Van den Broeck A, Maes H, Agostinis P, Roskams T, van den Oord JJ, Vankelecom H (2013) The human melanoma side population displays molecular and functional characteristics of enriched chemoresistance and tumorigenesis. PLoS One 8, e76550

Xu X, D'Hoker J, Stange G, Bonne S, De LN, Xiao X, Van de Casteele M, Mellitzer G, Ling Z, Pipeleers D, Bouwens L, Scharfmann R, Gradwohl G, Heimberg H (2008) Beta cells can be generated from endogenous progenitors in injured adult mouse pancreas. Cell 132:197-207

Xu Q, Yuan X, Tunici P, Liu G, Fan X, Xu M, Hu J, Hwang JY, Farkas DL, Black KL, Yu JS (2009) Isolation of tumour stem-like cells from benign tumours. Br J Cancer 101:303-311

Yin H, Price F, Rudnicki MA (2013) Satellite cells and the muscle stem cell niche. Physiol Rev 93:23-67

Yoshida S, Kato T, Susa T, Cai LY, Nakayama M, Kato Y (2009) PROP1 coexists with SOX2 and induces PIT1-commitment cells. Biochem Biophys Res Commun 385:11-15

Yoshida S, Kato T, Yako H, Susa T, Cai LY, Osuna M, Inoue K, Kato Y (2011) Significant quantitative and qualitative transition in pituitary stem/progenitor cells occurs during the postnatal development of the rat anterior pituitary. J Neuroendocrinol 23:933-943

Yoshida S, Kato T, Higuchi M, Chen M, Ueharu H, Nishimura N, Kato Y (2015) Localization of juxtacrine factor ephrin-B2 in pituitary stem/progenitor cell niches throughout life. Cell Tissue Res 359:755-766

Zhu X, Lin CR, Prefontaine GG, Tollkuhn J, Rosenfeld MG (2005) Genetic control of pituitary development and hypopituitarism. Curr Opin Genet Dev 15:332-340

Zhu X, Gleiberman AS, Rosenfeld MG (2007) Molecular physiology of pituitary development: signaling and transcriptional networks. Physiol Rev 87:933-963 